\title{
Overview of Cuba's Food Rationing System ${ }^{1}$
}

José Alvarez ${ }^{2}$

On October 28, 2000, U.S. President Bill Clinton signed the Trade Sanctions Reform and Export Enhancement Act (TSRA) which allowed U.S. firms to sell food and agricultural products to Cuba and other countries. However, the Cuban government did not purchase any of these products until December of 2001 following the devastating damage caused by Hurricane Michelle to important agricultural areas in November of that year.

Cuban purchases from U.S. firms amounted to $\$ 4.319$ million in 2001, \$138.635 million in 2002, and $\$ 256.9$ million in 2003. Cuba became the 35th most important food and agricultural export market for the United States in 2003, up from last (226th) in 2000. Actual purchases and pending contracts in the first-half of 2004 are at a pace to move Cuba into the top 20 most important markets of U.S. food and agricultural exports. Furthermore, because current U.S. legislation requires that all Cuban purchases from the United States must be conducted on a cash basis, the lack of credit risk associated with these sales makes Cuba one of the most attractive export markets for U.S. firms.

Anticipating changes in U.S.-Cuba trade relations, the Food and Resource Economics
Department at UF/IFAS initiated a research initiative on Cuba in 1990, including a 1993 collaborative agreement with the University of Havana, which has lasted to this day. (Most of the resulting publications can be found at http://www.cubanag.ifas.ufl.edu). We reiterate that our role as investigators is to provide the best available information and analyses from which rational decisions can be made. The reports included in this series intend to address the increasing level of interest in the Cuban market for food and agricultural products among U.S. firms and to assist them in becoming more familiar with that market. The complete list of documents in this series can be found by conducting a topical search for "Cuba" at http://edis.ifas.ufl.edu, or under "Additional Information" at the end of this document.

\section{Introduction}

Although some purchasing restrictions began in July of 1961 with the compulsory rationing of a few food items, such as meat and animal fats, food rationing was not officially established in Cuba until March of 1962. Since then, the issues of food scarcity, food security, and food crisis have commanded the attention of both supporters and detractors of the Cuban regime. Some supporters

1. This is EDIS document FE482, a publication of the Department of Food and Resource Economics, Florida Cooperative Extension Service, UF/IFAS, University of Florida, Gainesville, FL. Published July 2004. Please visit the EDIS website at http://edis.ifas.ufl.edu.

The author would like to thank the University Press of Florida (http://www.upf.com) for permission to reproduce material from the book Cuba's Agricultural Sector (Alvarez, 2004).

2. José Alvarez, Professor, Department of Food and Resource Economics, Everglades Research and Education Center, Belle Glade, FL, Florida Cooperative Extension Service, UF/IFAS, University of Florida, Gainesville, FL.

The Institute of Food and Agricultural Sciences is an equal opportunity/affirmative action employer authorized to provide research, educational information and other services only to individuals and institutions that function without regard to race, color, sex, age, handicap, or national origin. For information on obtaining other extension publications, contact your county Cooperative Extension Service office. Florida Cooperative Extension Service/Institute of Food and Agricultural Sciences/University of Florida/Christine Taylor Waddill, Dean. 
have gone as far as identifying the U.S. economic sanctions against Cuba as the main culprit. Some detractors have left the island simply because no hay comida (there is no food). This fact sheet presents an overview of the history and functioning of Cuba's food rationing system. Issues related to food security are discussed in another fact sheet of this series (EDIS FE483).

\section{Brief Historical Background}

The reasons for the introduction of a system of food rationing in revolutionary Cuba just three years after the revolution can be found in a combination of two factors. The first factor was the increasing demand for food as a result of more purchasing power for the public (increasing incomes and decreasing expenses such as rent and electricity). The second factor was decreasing food production as a result of the drastic changes taking place in farm ownership and organization.

Food rationing was officially established in Cuba by Law No.1015 on March 12, 1962, with the distribution of one rationing booklet (libreta) to every household. (The term used was núcleo familiar.) A household could be composed of one or more individuals and there could be more than one household per dwelling. The administration of the rationing system was placed in the hands of the Ministry of Internal Trade (MINCIN).

Practically all food items were included in the initial rationing scheme. Each household was entitled to purchase a specific quantity of the rationed items, depending on the number of consumers on the ration booklet issued to each household. The items subject to quotas have not remained static over time. As production of some fruits and/or vegetables increased, they were taken out of the rationing system and sold freely (por la libre); when they became scarce again, they were returned to the ration booklet. Eggs are perhaps the best example of items that have moved in and out of the libreta.

Interpreting the information from the evolving quotas under the rationing system over time (Table 1) is misleading for several reasons:
- many Cubans have access to subsidized lunches in their workplaces.

- children living in boarding schools still receive their household quotas despite their being away from home and those attending regular schools are provided lunch at school.

- eating away from home is an alternative for a small segment of the population.

- many of the items from the initial ration booklet were the result of excessive optimism on the part of the planners but were never available (The long list included items such as different types of ham, cheese, pepperoni, and sausage; all cuts of beef, pork, lamb, and goat; and fish, seafood, fruits, and vegetables were listed by name. Such an unrestricted list of food intended for distribution at the very outset of establishing a rationing system did not escape the Cubans' sense of humor).

- buying food in the black market has been an alternative during most of the period that rationing has existed.

Establishing the Special Period in Time of Peace in 1990, legalizing holdings of foreign currency and remittances from abroad in 1993, and creating free agricultural markets in 1994 added new dimensions to the food-rationing scenario. Decreasing food production meant fewer agricultural products were available through the ration booklet at government stores (Alvarez, 2004). At the same time, food at the agricultural markets was becoming an alternative even at prices high in comparison to the purchasing power of most Cubans. These conditions helped establish other outlets for the sale of agricultural and meat products.

The authorization for self-employment in late 1993 introduced neighborhood eateries called paladares as an alternative to regular restaurants which charge customers in U.S. dollars. According to Scarpaci (1995, p. 76), most paladares cater largely to Cubans and charge mainly in Cuban pesos. In addition, the paladares must pay hefty fees to the government to open and operate them. Although not accessible to most of the population because of their 
cost, this option does offer an alternative to Cuba's food scarcity.

\section{Who or What Is Responsible for Food Rationing?}

While many supporters of the Cuban regime blame the U.S. economic sanctions (that the Cubans refer to as a blockade) against Cuba as the main culprit, almost all of the detractors place the burden on the inefficiencies of the socialist system. Given the importance of this issue in terms of the hardships it has represented to the population on the island for more than 40 years, the two points of view deserve careful analysis.

As stated above, for supporters of the Cuban regime, the United States is the culprit. The following quote is very revealing because it blames the United States for the suffering of the Cuban people under the rationing system, and because it states (for the first time, to our knowledge) the cost of administering such a system:

As a consequence of the U.S.-imposed economic blockade, Cuba was forced to establish a rationing system for basic food and industrial products. This has brought serious limitations to consumers and their choice availability. Since the establishment of the economic blockade, consumers have had to adapt themselves to the limits of quantity and of choice offers that are available, instead of choosing according to preference and custom. Cuba also had to establish a whole Government-agency organization, called Consumer's Register Control Office, to keep accurate records of consumers, quotas and ration booklets all over the country. The operation of this control system results in an increase in annual budget expenditures of $7,000,000$ Cuban pesos, not including control expenditures over wholesale and retail commerce, to ensure compliance with the established regulations (León Cotayo, 1991, pp. 59-60).

Thus, the cost of administering the food rationing system around 1990 is set at seven million Cuban pesos (around US\$300,000), which must be larger now. At any rate, the figure represents a high monetary price the Cubans have to pay to support a rationing system that has been in effect for more than 40 years.

In terms of the additional costs of the economic sanctions, the Cuban government has provided some figures. For example, in an official report submitted to the United Nations, it is reported that, in the year 2000, Cuba had to pay an additional 38 million dollars to purchase food as a result of the price differentials between the United States and alternative markets. In addition, the costs of financing around $63 \%$ of the food imports in the same year demanded expenses greater than $\$ 50$ million. Under normal conditions, these expenses would not have been greater than $\$ 19$ million (this information is contained in a report the Cuban government sent to the United Nations on July 17, 2001, and placed on the La Nueva Cuba website).

The previous report was rebutted by a Cuban independent journalist (Espinosa Chepe, 2001). According to him, Cuba devotes between $\$ 800$ million and $\$ 900$ million, more than $20 \%$ of its import capacity, to the purchase of food that could be very easily produced in the country. Such purchases, which do not satisfy the needs of the population, are made abroad as the result of the inefficiency that exists in the agricultural sector. That state of affairs, he says, is not the result of any embargo but a consequence of the commanding incompetence.

There is no question about the unequivocal damage that U.S. economic sanctions have had on the Cuban economy. However, they are far from being the main reason for the current state of affairs. One has to distinguish between the Cuban economy in general and "a rationing system for basic food and industrial products" as quoted above.

To blame U.S. economic sanctions for the existence of a rationing system of basic food products is not a very sound argument to justify Cuba's socialist system. It is an admission that Cubans cannot even produce what grows very easily on Cuban soil. If one lists the food products that have been rationed since 1962, it becomes evident that almost all of them were in abundance before the 1959 revolution and were produced domestically. Granted, 
some Cubans have been unable to consume a wide variety of food products because of the high prices under the rationing system, but there have been periods in which the abundance of several products have demonstrated the feasibility of returning to a stable and ample food supply. Examples include the proliferation of FrutiCuba (a chain of government stores) which was devoted exclusively to selling fruits and vegetables in the mid-1960s, free farmers' markets in the 1980s, the free agricultural markets after 1994, and the new food outlets. These testify to the ability of Cuban farmers to produce abundant food supplies despite U.S. economic sanctions. Domestic production could do away with the food rationing system. It is very relevant to recall that, when the Soviet bloc was subsidizing the Cuban economy to the tune of five billion dollars per year, food was still rationed in Cuba.

\section{Some Characteristics of the Rationing System}

The ration quota is distributed in what Cubans call bodegas and placitas. In its broadest definition, a bodega is an outlet for the selling of food products, or a food store. It can be a modern one, such as a supermarket, or a small one-door place. A placita is usually a small outlet for the distribution of fruits and vegetables, which is also known in Cuba as puesto. These are the two main outlets that sell rationed products. Many of these outlets had been in existence since pre-revolutionary times but were expropriated and later became the only outlets involved in the selling of rationed food. Others have been added in some neighborhoods while some have been closed with the passage of time.

\section{Daily Intake Supplied and Available Food Products}

According to Nova González (2000a, p. 146), it has been estimated that, on average, the rationed market supplies around $61 \%$ of the calories, $65 \%$ of the vegetable proteins, $36 \%$ of the animal proteins, and $38 \%$ of the fats of the daily diet of the Cuban population. Two issues have to be pointed out here. First, the figures will depend on when, how, and where they are measured. For example, in another publication, Nova González (2000b, p. 1) states that, in 1999, the rationed market contributed $49 \%$ of the calories, $40 \%$ of the vegetable proteins, $30 \%$ of the animal proteins, and $19 \%$ of the fats of the daily diet in the Ciudad de la Habana province. Second, the quantities of rationed goods allocated to households are greater in Havana than in other parts of the country.

Since the rationing system does not supply the daily required amounts of calories, proteins, and fats, Cubans who can afford it have to go to other food outlets to meet the minimum daily requirement, either in Cuban pesos at the agricultural markets or in U.S. dollars at special dollar stores.

\section{Impact of the Special Period}

The Special Period (established in September of 1990 to face the economic hardships resulting from the demise of the Soviet bloc) brought about sharp reductions in the availability of food products in the rationed market. More than 10 years after the beginning of the Special Period, quota amounts have yet to return to the level of the1980s. Dramatic examples of meager per capita quotas include one pound of chicken per month, six ounces of coffee (mixed with soybean or other product) per month, and six pounds of rice per month. Another problem is that, according to Díaz Vázquez (2000), the quotas are not supplied at the time they are due and in the quantities specified. Meat derivatives, distributed by novena (every nine days, rather than weekly, to save one quota per month), encompass: (a) fricandel, similar to sausages; (b) ground beef extendido or texturizado, a 50/50 blend of meat and soybean product; (c) mortadella, made from ground chicken and other ingredients; and (d) masa cárnica, includes meat balls and croquettes. The population refers to these meat products with the acronym OCNI (Objeto Comestible No Identificado), or non-identified edible object (2000, p. 51).

\section{Monthly Food Expenses}

It is hard to calculate the monthly food expenses of rationed goods because all items are not always delivered on time and because, in some instances, they are scheduled to be delivered bimonthly. Despite those difficulties, the monthly expenses for a household of four adults (no children, no one over 65, 
no special diets), were calculated under the assumption of the availability of all listed items during the month. The total monthly expenses amounted to between 140.35 and 162.79 Cuban pesos. The average monthly wage in Havana in 1998 was 217 pesos (CEE, 1998, p. 107). Therefore, food expenses in the rationed market for a family of four, under the assumptions made, amounted to around $70 \%$ of the monthly wage if only one person was working and about $18 \%$ of combined monthly wages if all four members of the household were employed. In per capita terms, the figures translate as between 35.09 and 40.70 pesos per month.

A much lower figure was calculated by Nova González (2000b). According to him, total monthly expenses on rationed food amounted to 66 Cuban pesos for a family of four in the city of Havana in 1999, or 16.50 Cuban pesos per person. The list of rationed food products, however, was not provided in the publication, making comparisons with the previous calculations impossible. He also calculated monthly expenses for the same family for food not purchased with the ration booklet. Those expenses amounted to an additional 590.70 Cuban pesos for the entire family, or 147.67 Cuban pesos per person. The total food bill, therefore, amounted to 656.70 Cuban pesos for the entire family, or 164.17 Cuban pesos per person.

The above figures are shocking indeed. With a monthly wage of 217 pesos, after spending 126.30 pesos on food, the average Cuban would be left with only 90.70 Cuban pesos per person to cover the rest of the living expenses, or 362.80 Cuban pesos for a working family of four. This situation urged the official newspaper Granma Internacional to publish an article entitled "More food, but still draining the family pocket" (Pagés, 2001).

Despite the fact that rationed products are sold at subsidized prices (fixed throughout the country), their supply always falls short. Since, according to the majority of Cubans, the rationed items are not enough to feed a person for the entire month, those who can afford it are forced to fulfill their needs for the remainder of the month (usually about two weeks) through purchases in other outlets where prices are much higher and/or where the purchases must be made with U.S. dollars.

\section{References}

Alvarez, José. 2004. Cuba's Agricultural Sector. Gainesville, FL: University Press of Florida.

Benjamin, Medea, Joseph Collins, and Michael Scott. 1986. No Free Lunch-Food and Revolution in Cuba Today. New York, NY: Grove Press.

CEE. Comité Estatal de Estadísticas. Annual Issues. Anuario Estadístico de Cuba. La Habana: Editorial Estadística.

Díaz Vázquez, Julio A. 2000. Consumo y Distribución Normada de Alimentos y Otros Bienes en Cuba." In La Ultima Reforma Agraria del Siglo-La Agricultura Cubana entre el Cambio y el Estancamiento, edited by Hans-Jürgen Burchardt, pp. 33-56. Caracas, Venezuela: Editorial Nueva Sociedad.

Dumont, Rene. 1970. Cuba, ¿Es Socialista? Caracas, Venezuela: Editorial Tiempo Nuevo.

Espinosa Chepe, Oscar. 2001. "La Gran Coartada." CubaNet Independiente, at: http://www.cubanet.org/CNews/y01/jul01/23a4.htm.

Handelman, Howard. 1981-1982. Cuban Food Policy and Popular Nutritional Levels. Cuban Studies 11 (2) \& 12 (1): 127-146.

León Cotayo, Nicanor. 1991. Sitiada la Esperanza. La Habana: Editorial Cultura Popular.

Nova González, Armando. 2000a. "El Mercado Agropecuario." In La Ultima Reforma Agraria del Siglo - La Agricultura Cubana entre el Cambio y el Estancamiento, edited by Hans-Jürgen Burchardt, pp. 143-150. Caracas, Venezuela: Editorial Nueva Sociedad.

Nova González. 2000b. El Mercado Interno y el Aceso a los Alimentos en Cuba. Centro de Estudios de la Economía Cubana, Universidad de la Habana, Ciudad de la Habana. Mimeographed.

Pagés, Raisa. 2001. Más Alimentos pero aún Siguen Drenando el Bolsillo Familiar. Granma Internacional, August 4. 
Scarpaci, Joseph L. 1995. The Emerging Food and Paladar Market in Havana. Cuba in Transition 5: 74-84.

\section{Additional Information}

Below is a list of the fact sheets in this series on Cuban Agriculture. They can be accessed by clicking on the highlighted links:

- FE479 - Cuban Agriculture Before 1959: The Political and Economic Situations

- FE480 - Cuban Agriculture Before 1959: The Social Situation

- FE481 - Transformations in Cuban Agriculture After 1959

- FE482 - Overview of Cuba's Food Rationing System

- FE483 - The Issue of Food Security in Cuba

- FE484 - Acopio: Cuba's State Procurement and Distribution Agency

- FE485 - Antecedents of the Cuban Agricultural Policies of the 1990s

- FE486 - Chronology of Cuban Reform Policies with Emphasis on Agriculture, 1993-1995

- FE487 - Cuba's Basic Units of Cooperative Production

- FE488 - Cuba's Agricultural Markets

- FE489 - Environmental Deterioration and Conservation in Cuban Agriculture

- FE490 - The Potential Correlation between Natural Disasters and Cuba's Agricultural Performance 
Table 1. Monthly rations of selected products in Cuba, selected years 1963-1995.

\begin{tabular}{|c|c|c|c|c|c|c|c|}
\hline Item & 1963 & $1969^{a}$ & 1972 & 1978 & 1980 & 1983 & 1995 \\
\hline & \multicolumn{7}{|c|}{ pound per person } \\
\hline Rice & 6 & $3-4$ & 6 & 5 & 5 & 5 & 5 \\
\hline Dry Beans & 1.5 & 1.5 & $1.5-3$ & 1.25 & 1.25 & 1.25 & 1.5 \\
\hline Cooking Fat & 2 & 2 & 2 & 1.25 & 1 & 1 & $N / A^{*}$ \\
\hline Beef & 3 & 3 & 3 & 1.67 & 1.25 & 1.25 & $\mathrm{~N} / \mathrm{A}$ \\
\hline Eggs (units) & 2 & $15-24$ & $15-24$ & $\begin{array}{c}\text { Not } \\
\text { Rationed }\end{array}$ & $\begin{array}{c}\text { Not } \\
\text { Rationed }\end{array}$ & $\mathrm{N} / \mathrm{A}$ & $N / A$ \\
\hline Fish & 1 & 2 & $\begin{array}{c}\text { Not } \\
\text { Rationed }\end{array}$ & $\begin{array}{c}\text { Not } \\
\text { Rationed }\end{array}$ & $\begin{array}{c}\text { Not } \\
\text { Rationed }\end{array}$ & $\mathrm{N} / \mathrm{A}$ & $6-9$ oz \\
\hline Milk, Fresh & $\mathrm{b}$ & $\mathrm{b}$ & $\mathrm{b}$ & $\mathrm{b}$ & $\mathrm{b}$ & $\mathrm{b}$ & $\mathrm{N} / \mathrm{A}$ \\
\hline Milk, Canned & 3 & 3 & 3 & 3 & 3 & 3 & $\mathrm{~N} / \mathrm{A}$ \\
\hline Bread & $\begin{array}{c}\text { Not } \\
\text { Rationed }\end{array}$ & 15 & $N / A$ & 15 & 15 & 15 & $\mathrm{~N} / \mathrm{A}$ \\
\hline Oil & $N / A$ & $\mathrm{~N} / \mathrm{A}$ & $N / A$ & $\mathrm{~N} / \mathrm{A}$ & $\mathrm{N} / \mathrm{A}$ & $8 \mathrm{oz}$ & $N / A$ \\
\hline Sugar, Refined & $N / A$ & $6 c$ & $N / A$ & $\mathrm{~N} / \mathrm{A}$ & $\mathrm{N} / \mathrm{A}$ & $N / A$ & 3/Household \\
\hline Sugar, Raw & $N / A$ & $N / A$ & $N / A$ & $\mathrm{~N} / \mathrm{A}$ & $\mathrm{N} / \mathrm{A}$ & $\mathrm{N} / \mathrm{A}$ & 3/Household \\
\hline Coffee & $N / A$ & $6 o z^{c}$ & $\mathrm{~N} / \mathrm{A}$ & N/A & $N / A$ & $4 \mathrm{oz}$ & N/A \\
\hline Chicken & $\mathrm{N} / \mathrm{A}$ & $N / A$ & $N / A$ & $\mathrm{~N} / \mathrm{A}$ & $\mathrm{N} / \mathrm{A}$ & $\mathrm{N} / \mathrm{A}$ & $3 \mathrm{oz}$ \\
\hline $\begin{array}{l}\text { Soy meal } \\
\text { (picadillo soya) }\end{array}$ & $N / A$ & N/A & $N / A$ & $N / A$ & $N / A$ & $\mathrm{~N} / \mathrm{A}$ & Varies \\
\hline \multicolumn{8}{|c|}{$\begin{array}{l}\text { Dumont's list (1970, pp. } 253-254) \text { differs on rice }(4 \mathrm{lbs}) \text {, beef }(4 \mathrm{lbs}) \text {, eggs ( } 15 \text { units), and no mention of cooking } \\
\text { fat or milk. It contains sugar (6 lbs), coffee }(6 \mathrm{oz}) \text {, and a few other products [lbs }=\text { pounds, oz }=\text { ounces]. } \\
\text { Children seven years of age and under receive one liter of milk daily as do the elderly, the ill, and pregnant } \\
\text { women. } \\
\text { " From Dumont (1970, p. } 253) \text {. } \\
\text { * N/A = No information available. } \\
\text { Sources: } 1963-1980: \text { Handelman (1981-1982, p. 136); 1969: Dumont (1970, pp. 253-254); 1983: Benjamin et al. (1986, p. } \\
\text { 35); 1995: Scarpaci (1995, p. } 75) \text {. }\end{array}$} \\
\hline
\end{tabular}

